\title{
PARAMETER PENENTU PENGGUNAAN TRANSPORTASI UMUM DI PERKOTAAN PATI
}

\author{
Determining Parameters for the Use of Public Transport in Pati Urban \\ Area
}

\section{Bekti Winarno ${ }^{1}$ dan Okto Risdianto Manullang ${ }^{2}$}

Received: 3 Oktober 2017

Accepted: 28 Februari 2018

\begin{abstract}
Abstrak: Penelitian ini bertujuan untuk menganalisis dan menguji parameter penentu penggunaan transportasi umum pada kelompok choice user pekerja di Perkotaan Pati sehingga diketahui parameter penentu apa yang paling dominan. Objek penelitian adalah persepsi para pekerja yang bekerja di Perkotaan Pati dengan 150 sampel yang dipilih secara non-probability sampling dengan teknik Purposive Sampling. Teknik analisis yang digunakan adalah Analisis Stuctural Equation Modelling (SEM), dengan Maximum Likelihood Estimation (MLE). Penelitian ini membuktikan bahwa aksesibilitas, konektivitas dan kualitas layanan berpengaruh positif dan signifikan terhadap ketidakpuasan pengguna; dan ketidakpuasan pengguna berpengaruh positif dan signifikan terhadap perilaku tidak menggunakan transportasi umum. Akan tetapi pengaruh biaya perjalanan terhadap penggunaan transportasi umum tidak dapat dijelaskan oleh karena tidak dapat dilakukan estimasi. Menjawab permasalahan penelitian, penelitian ini menunjukkan bahwa parameterparameter konektivitas (yaitu waktu menunggu, kesesuaian jadwal dan waktu perjalanan) merupakan parameter penentu penggunaan transportasi umum paling dominan dengan pengaruh sebesar 0,562. Selanjutnya parameter-parameter aksesibilitas (yaitu waktu mencapai, kedekatan dan ketersediaan jalan ke pemberhentian) dengan pengaruh sebesar 0,462 dan parameterparameter kualitas layanan (yaitu perilaku petugas, kemanan dan keselamatan serta kenyamanan kendaraan) dengan pengaruh yang terendah sebesar 0,451. Penelitian juga mengkonfirmasi bahwa penggunaan transportasi umum ditentukan oleh kepuasan penggunanya.
\end{abstract}

Kata kunci: aksesibilitas, konektivitas, kualitas layanan, transportasi umum

Abstract: The research aims to analyze and assess determining parameters for public transportation usage for choice user group among the labours that work in Pati Urban Area; therefor the most dominant parameters will be known. User satisfaction recently used in public transportation researches and widely believed as determinant of mode choice. This research is using Structural Equation Modelling (SEM) Analysis with 150 sampels of Pati Urban Area labours (including public servant and private workers) choosen by purposive sampling technique. The findings of the reasearh are : connectivity, accessibility and service quality have positive and significant impact toward user disatisfaction and user disatisfaction influences traveller behaviour to unuse public transportation services, while influence of travel cost couldn't be explained and estimated. Finally, answering the research question, research reveals that connectivity's parameters $(0,563$ influence rate), i.e waiting time, desireable arrival schedule and travel time, are the most dominant to determine public transportation usage with accessibility's parameters $(0,462)$ at the next ranking. At the lower rangking but also significant are service quality's parameters with 0,451 influence rate.

Keywords: accessibility, connectivity, public transportation, service quality

\footnotetext{
${ }^{1}$ Badan Perencanaan Pembangunan Daerah Kabupaten Pati

${ }^{2}$ Departemen Perencanaan Wilayah dan Kota Fakultas Teknik Universitas Diponegoro
} 


\section{PENDAHULUAN}

Tidak seorang pun dapat menyangkal bahwa moda angkutan umum menggunakan ruang jalan jauh lebih efisien daripada moda angkutan pribadi (Tamin, 2000). Upaya mengembangkan kebijakan transportasi umum tidak akan berhasil jika para pengambil kebijakan tidak memahami kebutuhan pilihan dan permintaan para penggunanya. Namun demikian, tantangan terbesarnya adalah untuk mengidentifikasi parameter penentu pilihan para pejalan (Chuen dkk, 2014). Berbagai faktor mempengaruhi masyarakat dalam pilihan menggunakan kendaraan umum, diantaranya adalah waktu (travel time), jarak dan biaya perjalanan (Wang dan Liu, 2015); karakteristik pengguna (yaitu latar belakang, tingkat pendapatan keluarga, kepemilikan kendaraan dan ketersediaan pilihan kendaraan), karakteristik perjalanan (yaitu tujuan, waktu dan jarak) dan karakteristik fasilitas transportasi (yaitu durasi dan biaya perjalanan, kualitas layanan dan ketersediaan ruang parkir) (Chuen dkk, 2014); karakteristik pengguna, tujuan perjalanan, fasilitas moda dan karakteristik zona/kota (Tamin, 2000); kapasitas ruang parkir, aksesibilitas, biaya dan waktu perjalanan, kepastian, keamanan dan kenyamanan, serta alasan lingkungan (Corpuz, 2007). Papaioannou dan Martinez (2015) meyakini bahwa untuk menarik pengguna baru transportasi umum perlu dilakukan perubahan pada struktur jaringan transportasi, yaitu aksesibilitas dan konektivitas. Sementara itu, berbagai penelitian akhir-akhir ini mengaitkan antara kepuasan pengguna dengan perilaku memilih transportasi umum. Gebeyehu dan Takano (2008) menyatakan bahwa derajat kepuasan pengguna merupakan salah satu penentu pemilihan moda. Konsep yang awalnya berasal dari praktek manajemen pemasaran ini sesuai untuk melakukan analisis pilihan menggunakan transportasi umum, dilandasi pemikiran bahwa moda transportasi merupakan suatu produk dan pengguna merupakan konsumen (Shiftan dkk, 2015).

Membahas tentang pilihan moda transportasi tentu saja berkaitan dengan segmentasi penggunanya yang dapat dibedakan menjadi dua, yaitu mereka yang menggunakan transportasi umum sebagai pilihan (choice user) dan mereka yang tidak memiliki pilihan selain menggunakan transportasi umum (captive user). Beimborn dkk (2003) memberikan pandangan bahwa menjadi choice user karena tersedia pilihan transportasi yang realistis yang menghubungkan asal dan tujuan mereka sesuai dengan kebutuhan dan sejalan dengan berbagai kendala dalam kesehariannya. Mereka memilih menggunakan transportasi umum ketika merasa bahwa pilihan menggunakan transportasi umum lebih baik dibandingkan dengan pilihan lainnya. Sebaliknya captive user bergantung pada transportasi umum karena faktor usia, disabilitas, pendapatan atau kondisi keluarga dan seringkali kelompok ini tidak diperhitungkan. Oleh karena itu, pasar untuk peningkatan pilihan penggunaan transportasi umum adalah pada kelompok choice user.

Jika dilihat dari tujuan perjalanan, Tamin (2000) menyatakan bahwa perjalanan dengan maksud bekerja merupakan perjalanan yang dominan, dan karena itu sangat penting diamati. Jika ditinjau lebih jauh lagi akan dijumpai kenyataan bahwa lebih dari $90 \%$ perjalanan berbasis tempat tinggal, artinya dimulai dari rumah dan diakhiri kembali ke rumah.

Fenomena menurunnya, dan rendahnya, penggunaan transportasi umum terjadi dimana-mana. Di Provinsi Jawa Tengah, animo masyarakat menggunakan angkutan umum di Jawa Tengah cenderung menurun sehingga menyebabkan jumlah angkutan umum menurun. Pada Tahun 90-an jumlah armada transportasi umum mencapai 12 ribuan tetapi saat ini hanya berkisar lima ribuan (Ryanto, suaramerdeka.com, 23 April 2016). Demikian pula di Kabupaten Pati, angkutan umum juga belum menjadi pilihan utama masyarakat untuk melakukan perjalanan dengan distribusi pemilihan moda transportasi didominasi oleh penggunaan sepeda motor sebesar $73 \%$, mobil pribadi $9 \%$, dan mobil penumpang umum (MPU) 7\% (RUJTJ Kab. Pati, Bappeda Kab. Pati, 2015). Di sisi lain, besarnya 
penggunaan kendaraan pribadi berkaitan dengan tingginya kejadian kecelakaan yang melibatkannya, yaitu 73\% kejadian kecelakaan dari 817 kejadian kecelakaan pada Tahun 2014 melibatkan sepeda motor. Hal demikian semakin menegaskan perlunya meningkatkan penggunaan kendaraan umum sebagai pilihan perjalanan, khususnya di Kabupaten Pati. Perkotaan Pati, sebagai Ibu Kota Kabupaten Pati, salah satu kawasan strategis pertumbuhan ekonomi dan pusat kegiatan lokal, merupakan tujuan utama masyarakat Kabupaten Pati untuk bekerja, baik pekerja pemerintah maupun pekerja swasta. Jika merujuk pada statistik penggunaan kendaraan umum yang masih sangat rendah, patut diduga kelompok pekerja pun termasuk mereka yang mendominasi menggunakan kendaraan pribadi untuk tujuan bekerja yang merefleksikan ketidakpuasan mereka atas layanan transportasi umum sehingga tidak memilih menggunakannya.

Dalam rangka meningkatkan pilihan masyarakat menggunakan transportasi umum, penelitian tentang parameter penentu menggunakan atau tidak menggunakan transportasi umum pada kelompok choice user pekerja kemudian menjadi menarik, terutama dalam hal parameter manakah yang memiliki pengaruh terbesar sehingga dapat menjadikan bahan masukan bagi pemerintah daerah dalam menyusun kebijakan pada sektor transportasi di wilayahnya. Penelitian ini bertujuan untuk menganalisis dan menguji parameter penentu penggunaan transportasi umum pada kelompok choice user transportasi umum di kalangan pekerja di Perkotaan Pati sehingga diketahui parameter yang paling dominan.

\section{Kajian Parameter Penentu Penggunaan Transportasi Umum}

Berbagai penelitian menemukan bahwa terdapat berbagai parameter penentu penggunaan transportasi umum yang beragam dan dapat dikelompokkan sebagai :

a. Ciri pengguna atau atribut pengguna, dengan parameter-parameter : Ketersediaan atau pemilikan kendaraan pribadi; kepemilikan Surat Izin Mengemudi (SIM); struktur rumah tangga; pendapatan; dan keharusan menggunakan mobil ke tempat bekerja dan keperluan mengantar anak sekolah (Tamin, 2000); karakteristik sosio-demografik pejalan; akses atau ketersediaan kendaraan pribadi; alasan lingkungan (Corpuz, 2007); dan ketertersediaan dan kebutuhan kendaraan pribadi (termasuk membawa barang/anak) dan/atau SIM; pertimbangan aspek lingkungan (Wang dan Liu, 2015).

b. Ciri Pergerakan atau atribut perjalanan, dengan parameter-parameter : tujuan pergerakan; waktu terjadinya pergerakan; jarak perjalanan (Tamin, 2000); tujuan perjalanan dan waktu dilakukannya perjalanan (Corpuz, 2007); tujuan perjalanan (Chuen dkk, 2014); dan jarak tujuan (Wang dan Liu, 2015).

c. Ciri fasilitas moda transportasi, karakteristik fasilitas transportasi, kualitas layanan, atau kebergunaan dan keamanan, dengan parameter-parameter : kenyamanan dan keamanan, keandalan, keteraturan (Tamin, 2000); kenyamanan (Corpuz, 2007); kondisi ruang penumpang dan keandalan (Chuen dkk, 2014); kenyamanan (stres di jalan); keandalan layanan; keselamatan personal (Wang dan Liu, 2015); dan kenyamanan naik turun, informasi turun dan berpindah kendaraan lain, dapat membawa apa saja untuk perjalannya, dan keamanan dan keselamatan di dalam kendaraan (Beimborn dkk, 2003).

d. Aksesibilitas, dengan parameter-parameter : waktu perjalanan ke tempat pemberhentian (Tamin, 2000); akses ke layanan transportasi (Corpuz, 2007); jarak aksesibilitas (Chuen dkk, 2014); dan kedekatan sistem dengan rumah (Wang dan Liu, 2015); waktu untuk mencapai jaringan transportasi umum dan kedekatan (proximity) tempat pemberhentian transportasi umum, dengan lokasi asal maupun tujuan (Papaioannou dan Martinez, 2015); kemudahan menjangkau pemberhentian asal dan pemberhentian tujuan, serta ketersediaan fasilitas parkir (umumnya disebut penitipan) di dalam jaringan (Beimborn dkk, 2003); waktu berjalan/ mencapai dari asal dan tujuan menuju pemberhentian (Chowdhury dkk, 2014). 
e. Konektivitas (atau ada yang menyebut interkonektivitas), dengan parameter-parameter : waktu perjalanan, terdiri dari waktu menunggu di tempat pemberhentian bus, waktu selama bergerak, dan lain-lain (Tamin, 2000); frekuensi layanan transportasi umum dan waktu perjalanan (Corpuz, 2007); konektivitas jaringan, frekuensi layanan, waktu perjalanan (Chuen dkk, 2014); waktu perjalanan; ketersediaan dan frekuensi layanan sesuai jadwal (Wang dan Liu, 2015); waktu menunggu, waktu perjalanan di dalam kendaraan, dan waktu berpindah moda (Papaioannou dan Martinez, 2015); ketersediaan layanan asal -tujuan dan layanan kembali yang sesuai dengan jadwal pengguna (Beimborn dkk, 2003); dan waktu perjalanan dalam kendaraan dan waktu menunggu (Chowdhury dkk, 2014).

f. Biaya Perjalanan, dengan parameter-parameter : tarif (Tamin, 2000; Corpuz, 2007; Chuen dkk, 2014) dan biaya lain-lain yang timbul dalam perjalanan (Tamin, 2000);

g. Hambatan kendaraan pribadi, dengan parameter-parameter : Ketersediaan tempat parkir untuk kendaraan pribadi (Tamin, 2000; Corpuz, 2007; Chuen dkk, 2014; Wang dan Liu, 2015) dan kepadatan lalu lintas/traffic (Chuen dkk, 2014).

Sementara itu, De Vos dkk (2015) meyakini bahwa perilaku memilih moda transportasi selain dipengaruhi oleh perangkat moda juga dipengaruhi oleh perasaan pengguna atau pengalaman menggunakan moda transportasi yang sangat erat kaitannya dengan kepuasan. Kepuasan dapat dimaknai sebagai hasil perbandingan antara kenyataan dan harapan. Orang akan merasa puas ketika persepsi terhadap layanan yang mereka terima sesuai dengan harapan. Ketika layanan kurang dari yang diharapkan, mereka akan menjadi tidak puas dan menjadi enggan menggunakannya dan memilih moda yang lain (Gebeyehu dan Takano, 2008). Beberapa penelitian tentang penentu kepuasan dan ketidakpuasan pengguna transportasi umum menyimpulkan bahwa kepuasan ditentukan oleh kualitas layanan, aksesibilitas dan konektivitas (Gebeyehu dan Takano, 2008; Abenoza dkk, 2017; Lierop dan El-Geneidy, 2016; Shiftan dkk, 2015).

Oleh karena subjek penelitian ini adalah para pekerja dengan ciri perjalanan untuk keperluan bekerja serta bertempat tinggal di sekitar Perkotaan Pati, maka beberapa kelompok parameter tidak akan digunakan sebagai kelompok parameter penentu penggunaan transportasi umum dalam penelitian ini. Justifikasi tidak digunakannya beberapa kelompok parameter adalah sebagai berikut :

a. Karakteristik pejalan tidak dipertimbangkan oleh karena obyek penelitian adalah kelompok choice user pekerja komuter yang diasumsikan secara sosial ekonomi tidak terlalu berbeda dan secara lokasi asal dan tujuan juga tidak terlalu berbeda, yaitu bertempat tinggal di kecamatan sekitar Perkotaan Pati dan tujuan bekerja di Perkotaan Pati.

b. Karakteristik perjalanan tidak dipertimbangkan oleh karena tujuan perjalanan obyek yang diteliti adalah tujuan perjalanan untuk bekerja dengan waktu perjalanan yang relatif seragam pada pagi (berangkat) dan siang/sore (pulang).

c. Faktor ketersediaan parkir untuk kendaraan pribadi pada beberapa penelitian ditemukan sebagai faktor yang berpengaruh signifikan, namun demikian pada penelitian ini tidak dipertimbangkan oleh karena penelitian ini mencoba berfokus pada layanan transportasi umum

Berdasarkan pertimbangan bahwa tingkat penggunaan transportasi umum di lokasi penelitian yang sangat rendah (sebesar 7\%), yaitu pilihan moda transportasi didominasi dengan penggunaan kendaraan sepeda motor (73\%) dan mobil pribadi (9\%), patut diduga bahwa di kalangan kelompok choice user pekerja di lokasi penelitian saat ini lebih banyak yang memilih menggunakan transportasi privat (sepeda motor dan mobil) yang mengindikasikan ketidakpuasan pengguna terhadap moda transportasi umum yang ada. Oleh karena itu, model konseptual penelitian ini adalah sebagaimana Gambar 1. 
Tabel 1. Variabel dan Parameter Penelitian

\begin{tabular}{ll}
\hline Variabel & \multicolumn{1}{c}{ Parameter } \\
\hline Aksesibilitas & - Waktu untuk mengakses (mencapai) pemberhentian dan pemberhentian ke tujuan \\
(AKS1-AKS4) & - Kedekatan (proximity), yaitu jarak tempat pemberhentian transportasi umum \\
& - Ketersediaan jalan/jalur dari asal ke pemberhentian dan dari pemberhentian ke \\
& - Kujuan \\
& - peamanan pada saat berada di pemberhentian dan pada saat menuju/dari \\
Konektivitas & Ketersediaan layanan dari asal ke tujuan (dan perjalanan kembali) sesuai dengan \\
& - Wadwal \\
(KNV1-KNV5) & - Waktu untuk menunggu \\
& - Kemudahan untuk berpindah moda (ease of transfer) \\
& - Waktu untuk berpindah moda (transfer time) \\
Kualitas Layanan & Kenyamanan di kendaraan (naik turun kendaraan dan kondisi ruang \\
& - Kenumpang/kabin) \\
(KLA1-KLA4) & - Keandalan (perilaku pengemudi dan petugas pembayaran dalam melayani \\
& - Kenumpang) \\
Biaya Perjalanan & - Tarif layanan \\
(BIP1-BIP2) & - Biaya lain-lain yang timbul dalam perjalanan \\
Kepuasan Pengguna & - Kesesuaian antara harapan dan layanan yang diterima. \\
(TPUAS1-TPUAS3) & - Pernyataan bahwa menggunakan transportasi umum adalah pilihan tepat. \\
& - Pernyataan bahwa transportasi umum dikelola dengan baik. \\
Memilih & - Penggunaan ulang transportasi umum ketika melakukan perjalanan di masa \\
Menggunakan & datang. \\
Transportasi Umum & Merekomendasikan penggunaan transportasi umum kepada teman atau rekan \\
(TPIL1-TPIL2) & kerja \\
\hline
\end{tabular}

Sumber : penelitian terdahulu yang dikaji, 2017

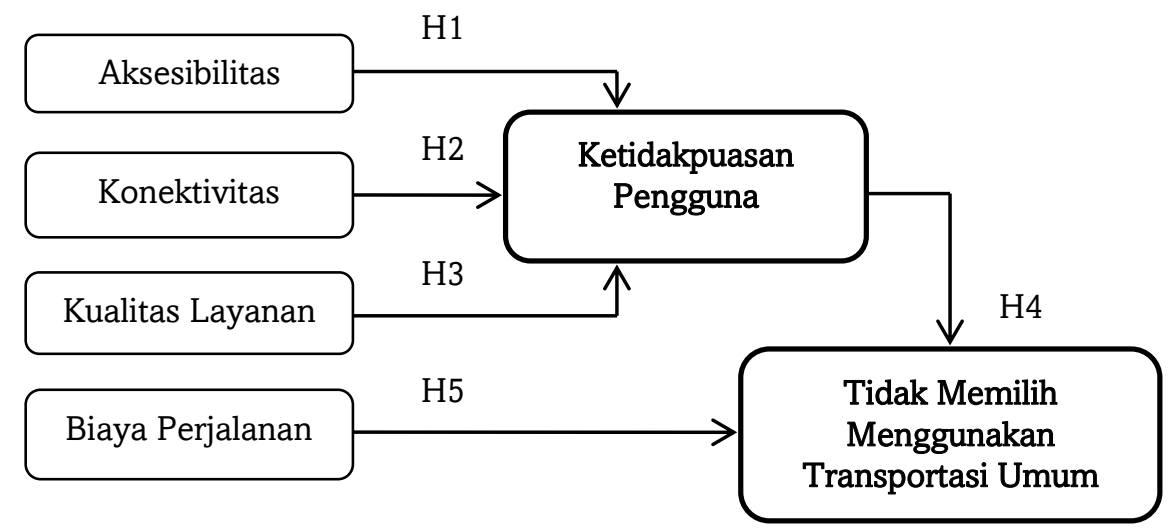

Sumber : penelitian terdahulu yang dikaji, 2017

\section{Gambar 1. Model Konseptual Penelitian}

Model tersebut menjelaskan bahwa parameter penentu kelompok choice user pekerja untuk tidak memilih transportasi umum dalam perjalanannya adalah : aksesibilitas, konektivitas, kualitas layanan, dan biaya perjalanan. Ketidakpuasan pengguna diyakini terkait dengan perilaku tidak memilih menggunakan transportasi umum. Sementara itu 
ketidakpuasan pengguna ditentukan oleh kinerja jaringan (dalam hal ini aksesibilitas dan konektivitas) dan kualitas layanan.

Berdasarkan model konseptual penelitian yang telah disusun, selanjutnya dikembangkan 5 (lima) hipotesis penelitian yaitu : (1) Hipotesis 1 : aksesibilitas berpengaruh positif dan signifikan terhadap ketidakpuasan; (2) Hipotesis 2 : konektivitas berpengaruh positif dan signifikan terhadap ketidakpuasan; (3) Hipotesis 3 : kualitas layanan berpengaruh positif dan signifikan terhadap ketidakpuasan; (4) Hipotesis 4 : ketidakpuasan berpengaruh positif dan signifikan terhadap pilihan tidak menggunakan transportasi umum; dan (5) Hipotesis 5 : biaya perjalanan berpengaruh positif dan signifikan terhadap pilihan tidak menggunakan transportasi umum.

\section{Transportasi Umum di Perkotaan Pati}

Perkotaan Pati merupakan Ibukota Kabupaten Pati, terletak tepat di tengah-tengah Kabupaten Pati dan berada di Jalur Pantura Pulau Jawa yang menghubungkan Kota Semarang dan Kota Surabaya. Kawasan Perkotaan Pati meliputi 31 desa/kelurahan di sebagian besar Kecamatan Pati dan sebagian Kecamatan Margorejo. Kawasan ini merupakan salah satu Kawasan Strategis Pusat Pertumbuhan Ekonomi dan Pusat Kegiatan Lokal (PKL) Kabupaten Pati, sehingga kawasan ini menjadi tempat bekerja, tidak hanya penduduk Perkotaan Pati tetapi juga para pekerja yang datang dari kecamatan lain di Kabupaten Pati. Jaringan transportasi umum yang melayani tujuan ke Perkotaan Pati meliputi rute antar kota dalam provinsi (AKDP) dan angkutan dalam kabupaten (baik perkotaan maupun perdesaan). Seluruh jaringan transportasi umum menghubungkan Perkotaan Pati dengan seluruh Ibu Kota Kecamatan yang ada di Kabupaten Pati.

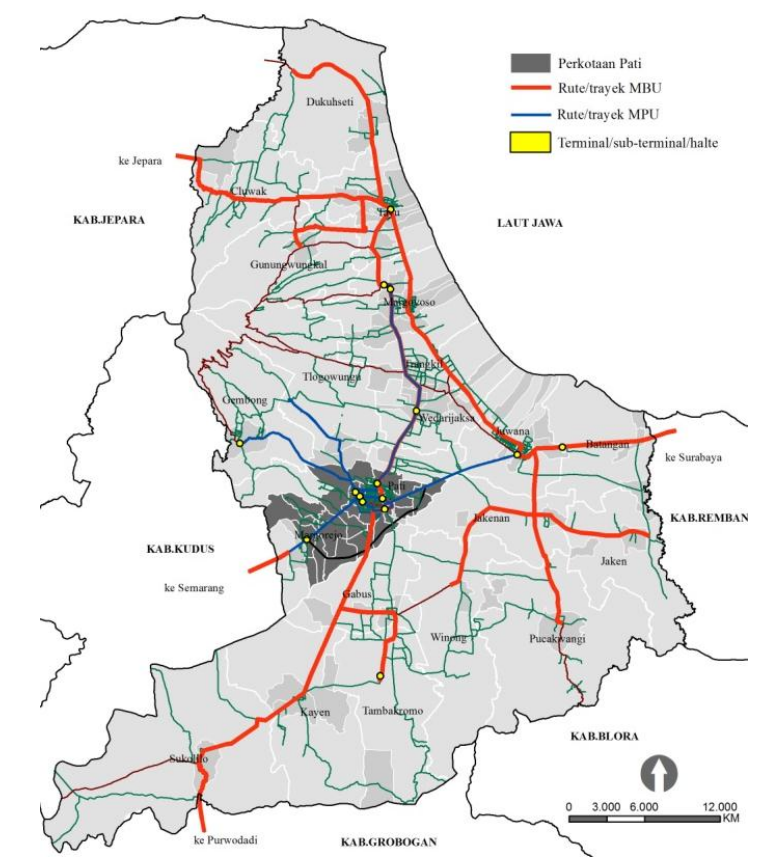

Sumber: RDTR Perkotaan Pati, 2014, RUJTJ Kab.Pati, 2015

Gambar 2. Peta Perkotaan Pati dan Jaringan Transportasi Umum 
Moda transportasi AKDP menggunakan bus, minibus, serta angkutan dalam kabupaten menggunakan mikro bus umum (MBU) dan mobil penumpang umum (MPU). Rute/trayek yang tersedia merupakan rute minibus umum (MBU) dan mobil penumpang umum (MPU), meliputi 11 trayek MBU dan 5 trayek MPU. Pemberhentian kendaraan umum biasanya digunakan untuk keperluan naik dan turun penumpang dan penumpang melakukan perpindahan moda. Namun demikian, sebagaimana layanan transportasi yang belum tertata dengan baik, penumpang transportasi umum di Kabupaten Pati dapat naik dan turun di sembarang tempat dalam jaringan. Pemberhentian utama transportasi umum di Perkotaan Pati adalah di Terminal Kembangjoyo, Terminal Juwana, dan Terminal Tayu dan Sub-terminal Pasar Puri serta beberapa halte yang disediakan baik di perkotaan maupun di luar perkotaan.

Penggunaan transportasi umum di Kabupaten Pati masih sangat rendah, yaitu sebesar $8 \%$, dibandingkan dengan moda transportasi lainnya, yaitu : sepeda motor $(73 \%)$, mobil pribadi (9\%), sepeda $6 \%$, dan berjalan kaki $4 \%$. Tingkat operasi kendaraan umum pada masing-masing trayek sebenarnya cukup baik, yaitu sebagian besar di atas $75 \%$ (RUJTJ Kab. Pati, 2015). Meskipun tingkat operasi kendaraan umum cukup tinggi, namun faktor muat (load factor) kendaraan umum di Kabupaten Pati sangat rendah, yaitu hanya berkisar antara 20-40\%. Jika dilihat pada aspek keterhubungan jaringan transportasi umum, konektivitas jaringan transportasi belum baik.

Frekuensi rata-rata (per jam) kendaraan umum pada seluruh rute sebarannya tidak merata, terdapat beberapa rute yang hanya dilayani sekali setiap jam dan secara umum 26 kendaraan tiap jam, meskipun terdapat rute dengan frekuensi 15 perjalanan per jam. Waktu tunggu kendaraan umum paling cepat 6 menit dan paling lama 62 menit. Waktu perjalanan berhubungan dengan panjang rute dan jika dihitung kecepatan kendaraan pada setiap rute, rata-rata kecepatan adalah $20-30 \mathrm{~km} / \mathrm{jam}$.

\section{METODOLOGI}

Penelitian ini adalah penelitian kuantitatif, yaitu variabel-variabel laten yang ada diwujudkan dalam variabel manifes (parameter/indikator) dan selanjutnya diwujudkan sebagai item-item pertanyaan dalam kuesioner sebagai instrumen pengumpulan data dari persepsi responden (baik pertanyaan tertutup maupun terbuka). Jawaban pertanyaanpertanyaan responden diukur dengan Skala Likert 5 angka sehingga hasilnya berbentuk angka (skor). Pertanyaan terbuka untuk menggali pendapat responden pada setiap item pertanyaan. Untuk menguji hipotesis, penelitian ini menggunakan Analisis Model Persamaan Struktural atau Stuctural Equation Modelling (SEM) dengan alat analisis Aplikasi Komputer AMOS 20.0. Mengacu pada Hair dkk (2010), terdapat 6 (enam) langkah dalam SEM yang merefleksikan terminologi dan prosedur yang unik SEM, yaitu: (1) Langkah 1: Menentukan konstruk (individual constructs); (2) Langkah 2: Mengembangkan model pengukuran; (3) Langkah 3: Mendisain studi untuk menyusun hasil empirik; (4) Langkah 4: Menguji validitas model pengukuran; (5) Langkah 5: Menentukan model struktural; dan (6) Langkah 6: Menguji validitas model struktural. Teknik estimasi yang digunakan adalah maximum likelihood estimation (MLE) yang diyakini lebih efisien dan tidak bias ketika dikaitkan dengan normalitas. MLE kini semakin banyak digunakan sebagai pendekatan dan umumnya merupakan pilihan default dalam aplikasi (komputer) untuk analisis SEM.

Selanjutnya analisis deskriptif dilakukan untuk mendapatkan deskripsi pendapat responden terkait parameter-parameter penentu yang diteliti berdasarkan jawaban pertanyaan terbuka. Pandangan responden mengenai apa yang ditanyakan dalam kuesioner dirangkum dengan cara pernyataan-pernyataan yang sama atau mirip digabungkan dalam satu kalimat yang representatif sehingga dapat memberikan gambaran 
temuan penelitian. Hasil analisis diharapkan dapat memberikan gambaran permasalahan pada setiap kelompok rute.

Subjek penelitian adalah para pekerja, yaitu mereka yang melakukan perjalanan untuk bekerja ke Perkotaan Pati, baik karyawan swasta maupun PNS yang bertempat tinggal di sekitar Perkotaan Pati. Oleh karena itu karakteristik subjek penelitian adalah : (1) bekerja di Perkotaan Pati; (2) bertempat tinggal di sekitar Perkotaan Pati; (3) melakukan perjalanan pulang-pergi setiap hari; dan (4) memiliki kendaraan pribadi tetapi pernah menggunakan transportasi umum (maksimal dalam 5 tahun terakhir). Secara pasti, populasi pekerja yang bekerja di Perkotaan Pati dengan kriteria yang telah disebutkan di atas sangat sulit ditentukan sehingga pemilihan sampel dilakukan dengan teknik purposive sampling. Ukuran sampel ditentukan dengan pertimbangan bahwa pada SEM dengan MLE sampel yang sesuai adalah antara 100-400 (Hair dkk, 2010; Ghozali, 2005 dalam Suhari, 2008), 150 sampel akan menghasilkan penyelesaian estimasi yang lebih baik (Anderson dan Gerbing, 1984 dalam Iacobucci, 2009), atau berdasarkan rasio yaitu sebanyak 5-10 kali parameter (Jenatabadi, n/d; Schreiber dkk, 2006). Oleh karena itu, penelitian ini menggunakan sampel sebanyak 150 responden. Selanjutnya jumlah sampel setiap grup ditentukan berdasarkan data jumlah pekerja yang tersedia, yaitu jumlah PNS sebesar 4.302 orang $(45 \%)$ dan karyawan swasta sebesar 5.222 orang $(55 \%)$. Data tersebut belum termasuk pekerja pemerintah di BUMN/D dan pekerja swasta di sektor perdagangan dan jasa (data tidak tersedia), sehingga proporsi sampel terdiri dari 60 responden pekerja pemerintah $(40 \%)$ dan 90 responden pekerja swasta $(60 \%)$.

\section{TEMUAN DAN DISKUSI}

Analisis SEM dilakukan menggunakan data isian kuesioner dari 150 responden terpilih, terdiri dari 84 laki-laki (56\%) dan 66 perempuan (44\%), sebagian besar berusia antara 21-30 tahun dan 31-40 tahun, masing-masing sebanyak 52 responden (34,67\%). Sebagaian besar responden menggunakan sepeda motor (62\%), sedangkan dalam hal menggunakan transportasi umum, $81(54 \%)$ responden melakukan perjalanan dengan transfer dan 69 responden (46\%) tanpa berpindah rute. Responden yang berpindah ruteterdiri dari 65 responden (43,33\%) menggunakan kombinasi MBU-MPU dan 16 responden (10,67\%) menggunakan kombinasi MPU-MPU. Sementara itu responden tidak melakukan transfer terdiri dari 16 responden (10,67\%) menggunakan MBU dan 53 responden (35,33\%) menggunakan MPU.
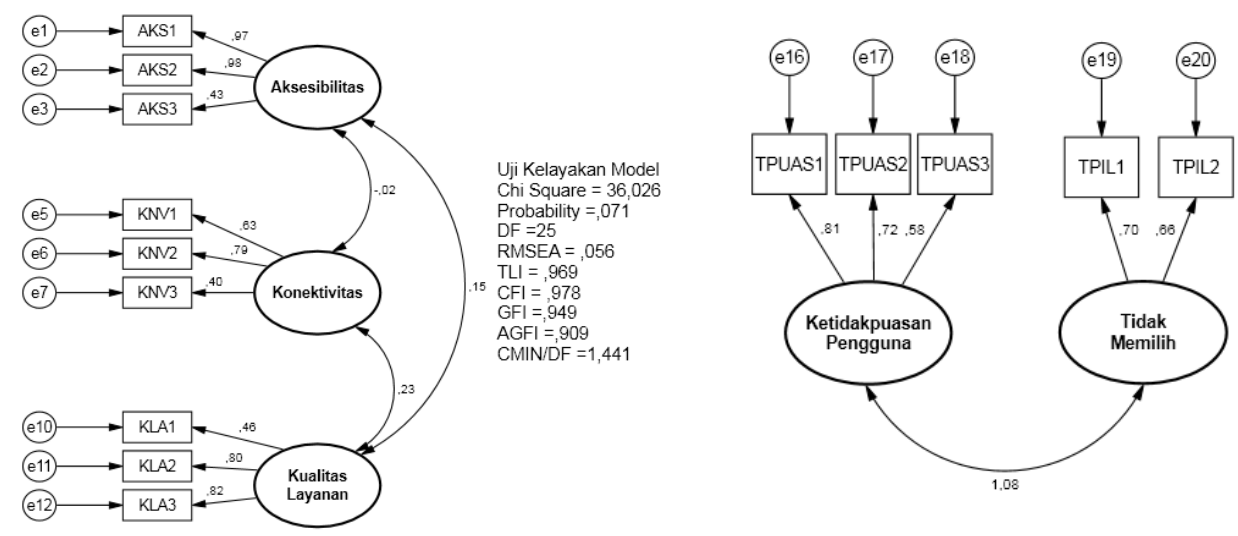

Uji Kelayakan Model Chi Square $=26,75$ Probability $=, 000$ $\mathrm{DF}=5$ RMSEA $=, 17$ $\mathrm{TLI}=, 839$
$\mathrm{CFI}=, 920$ $\mathrm{CFI}=, 920$ AGFI $=, 817$ $\mathrm{CMIN} / \mathrm{DF}=5,350$

Sumber: Hasil pengolahan data, 2017

Gambar 3. CFA Konstruk Eksogen dan Endogen 
Langkah keempat dalam analisis SEM adalah menguji validitas model pengukuran dengan analisis faktor konfirmatori (Confirmatory Factor Analysis/CFA) yang dilakukan untuk mengkonfirmasi apakah parameter-parameter yang digunakan dapat mengkonfirmasi sebuah faktor/variabel. Nilai loading factor setiap parameter diharapkan lebih dari 0,5 sehingga parameter-parameter dengan nilai loading factor kurang dari 0,5 akan dihapus dari model struktural. Hasil CFA konstruk eksogen dan endogen adalah sebagaimana Gambar 3.

Hasil akhir CFA konstruk eksogen menunjukkan bahwa model penelitian memenuhi kriteria goodness of fit/GOF (yaitu : chi-square kecil dengan $p>0,05$; RMSEA $\leq 0,08$; $\mathrm{TLI} \geq 0$,95; $\mathrm{CFI} \geq 0,95 ; \mathrm{GFI} \geq 0,90$; dan $\mathrm{CMIN} / \mathrm{DF}<2)$. Nilai probability menunjukkan nilai diatas batas signifikansi yaitu sebesar 0,071 karena itu model dapat diterima. Pengujian terhadap nilai-nilai loading factor setiap parameter menunjukkan hasil baik, yaitu nilai CR diatas 1,96. Sementara itu nilai loading factor sebagian besar parameter lebih besar dari 0,5 , walaupun terdapat parameter dengan nilai di bawah 0,5 yaitu parameter $\operatorname{KNV} 3(0,40)$, KLA1 $(0,46)$ dan AKS3 $(0,43)$ tetapi dengan nilai probabilitas lebih kecil dari 0,05 sehingga dapat dikatakan bahwa parameterparameter pembentuk variabel laten merupakan parameter yang kuat. Dengan pertimbangan tersebut, parameter dengan nilai loading factor mendekati 0,5 tetap akan digunakan dalam analisis selanjutnya. Oleh karena Variabel Biaya Perjalanan hanya memiliki 2 (dua) parameter, dan parameter BIP2 dihapus, maka Variabel Biaya Perjalanan selanjutnya tidak akan digunakan dalam model.

Pada CFA konstruk endogen, tidak semua kriteria GOF dapat terpenuhi dengan nilai probability di bawah batas signifikansi dan karena itu sebenarnya model belum dapat diterima. Namun, nilai GOF lainnya, yaitu CFI $(0,920)$ dan GFI $(0,939)$ memberikan konfirmasi yang cukup bahwa kedua variabel dapat mencerminkan variabel laten yang dianalisis. Hal tersebut juga didukung oleh nilai loading factor masing-masing parameter yang lebih dari 0,5. Selanjutnya dilakukan uji model struktural sekaligus untuk menganalisis hipotesis yang diajukan dengan hasil akhir sebagaimana Gambar 4.

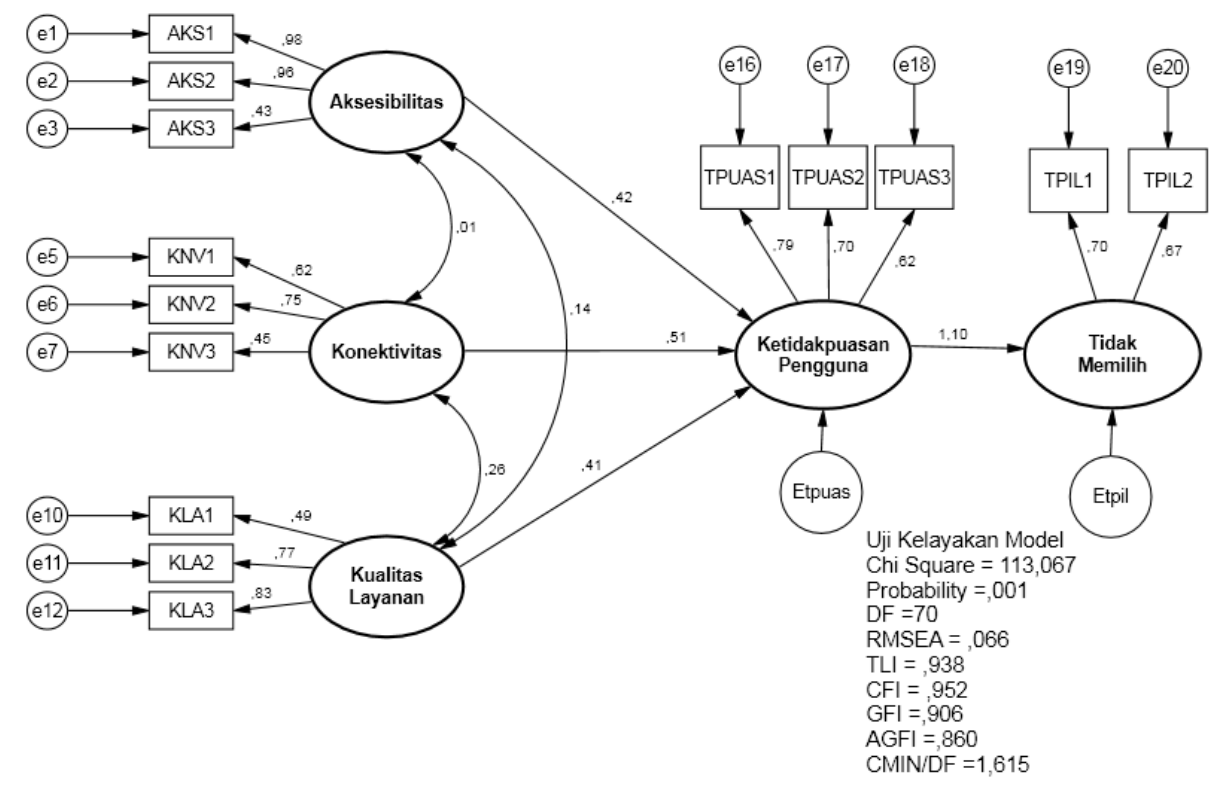

Sumber: Hasil pengolahan data, 2017

Gambar 4. Hasil Uji Model Struktural 
Hasil pengolahan data menunjukkan bahwa sebagian besar kriteria GOF telah memenuhi persayaratan. Sementara itu nilai probability menunjukkan nilai dibawah batas signifikansi yaitu sebesar 0,001 yang menunjukkan bahwa sebenarnya masih terdapat perbedaan antara matriks kovarians sampel dan matriks kovarians populasi yang diestimasi. Namun oleh karena sebagian besar nilai GOF yaitu RMSEA $(0,066)$, TLI $(0,938)$, CFI $(0,952)$, GFI $(0,906)$ dan CMIN/DF $(1,615)$ memenuhi ambang batas GOF sehingga memberikan konfirmasi yang cukup bahwa model memenuhi syarat, maka model dapat diterima. Berkaitan dengan estimasi MLE yang mensyaratkan penggunaan data yang terdistribusi normal, hasil perhitungan menunjukkan bahwa data terdistribusi normal, tidak terdapat nilai critical ratio (C.R) skewness dan curtosis yang berada di luar rentang yang disyaratkan antara $\pm 2,58$. Demikian pula dalam hal data outlier, sudah tidak terdapat outlier univariat maupun multivariat.

Dalam hal pengujian hipotesis, hasil estimasi menunjukkan bahwa hipotesis yang diajukan yaitu : aksesibilitas, konektivitas dan kualitas layanan berpengaruh positif dan signifikan terhadap ketidakpuasan pengguna; dan ketidakpuasan pengguna berpengaruh positif dan signifikan terhadap perilaku tidak menggunakan transportasi umum dinyatakan diterima, ditunjukkan dengan semua nilai $C R>1,96$ dan semua nilai $p$ sangat kecil $(0,000)$. Akan tetapi pengaruh biaya perjalanan terhadap penggunaan transportasi umum tidak dapat dijelaskan oleh karena variabel tersebut telah dihapus dan tidak dapat dilakukan estimasi..

Hasil estimasi juga menunjukkan bahwa aksesibilitas berpengaruh langsung pada ketidakpuasan pengguna sebesar 0,422 dan secara tidak langsung berpengaruh pada perilaku tidak memilih sebesar 0,462. Hal ini berarti ketika kualitas aksesibilitas menurun sebesar 1 maka ketidakpuasan pengguna meningkat sebesar 0,422 dan secara tidak langsung perilaku para pekerja komuter untuk tidak memilih transportasi umum meningkat sebesar 0,462. Sementara itu pengaruh langsung konektivitas terhadap kepuasan sebesar 0,513 dan pengaruh tidak langsung terhadap perilaku tidak memilih sebesar 0,563. Sedangkan pengaruh langsung kualitas layanan sebesar 0,422 dan pengaruh tidak langsung sebesar 0,462. Pengaruh langsung ketidakpuasan pengguna pada perilaku tidak memilih transportasi umum sangat besar, yaitu 1,906. Dengan demikian konektivitas merupakan penentu penggunaan transportasi umum yang paling dominan sehingga untuk meningkatkan kepuasan pengguna dan penggunaan transportasi umum, maka peningkatan konektivitas merupakan prioritas pertama.

Jika dilihat sebaran masalah terkait parameter penentu penggunaan transportasi umum sesuai persepsi responden, hasil analisis deskriptif menunjukkan bahwa rute dengan persepsi terburuk adalah Rute Pati-Kaliampo pada parameter aksesibilitas dan kualitas layanan serta Rute Pati-Gembong/Tlogowungu pada parameter konektivitas.

\section{KESIMPULAN}

Konektivitas, aksesibilitas dan kualitas layanan transportasi umum merupakan penentu penggunaan transportasi umum pada kelompok choice user pekerja yang bekerja di Perkotaan Pati. Konektivitas jaringan transportasi umum merupakan penentu paling dominan yang dapat dimaknai bahwa penurunan kualitas konektivitas memiliki pengaruh terbesar bagi tingkat kepuasan pengguna dan berdampak besar terhadap penggunaan transportasi umum.

Kualitas konektivitas transportasi umum dapat diukur terutama oleh parameter waktu menunggu. Parameter selanjutnya adalah kesesuaian jadwal layanan dengan jadwal perjalanan para pengguna dan waktu/kecepatan perjalanan. 
Parameter waktu untuk mencapai pemberhentian merupakan parameter paling kuat mengukur aksesibilitas, selanjutnya kedekatan tempat pemberhentian serta ketersediaan jalur/jalan menuju pemberhentian. Aksesibilitas jaringan transportasi umum yang rendah dan membutuhkan waktu lama untuk mencapai berkaitan dengan kondisi eksisiting jaringan transportasi umum saat ini hanya melalui jalan utama. Rute kendaraan umum yang demikian terkesan tanpa perencanaan yang sesuai dengan pemetaan asal dan tujuan perjalanan. Parameter perilaku pengemudi dan petugas pembayaran merupakan parameter paling kuat mengukur kualitas layanan, selanjutnya keamanan dan keselamatan dan kenyamanan di kendaraan. Pelayanan transportasi umum yang ada dilaksanakan tanpa suatu standar pelayanan.

Hasil penelitian sejalan dengan penelitian sebelumnya bahwa aksesibilitas, konektivitas dan (kualitas layanan) sistem transportasi umum yang baik dapat mendorong penggunaan transportasi umum dan menarik para pengguna transportasi privat beralih menggunakan transportasi umum. Sebaliknya, jika aksesibilitas dan konektivitas buruk akan menghalangi penggunaannya (Papaioannou dan Martinez, 2015; Beimborn dkk, 2003; Chowdhury dkk, 2014). Namun, tidak semua parameter merupakan parameter yang kuat mengukur konektivitas, aksesibilitas dan kualitas layanan. Parameter kemudahan untuk berpindah moda, waktu untuk berpindah moda dan keamanan menuju dan pada saat di pemberhentian bukan merupakan parameter yang kuat untuk mengukur konektivitas dan aksesibilitas. Sementara itu parameter kondisi fasilitas pemberhentian bukan merupakan parameter yang kuat untuk mengukur kualitas layanan. Hal ini dikarenakan sistem transportasi di kota kecil seperti Perkotaan Pati masih sederhana sehingga cukup banyak pengguna hanya menggunakan satu rute dalam perjalanannya. Akses menuju jaringan transportasi umumnya aman dari tindak kriminal dan tidak semua pemberhentian disediakan halte (pengguna dapat naik dan turun di sembarang tempat sepanjang rute).

Penelitian ini juga mendukung pendapat bahwa perilaku memilih moda transportasi dipengaruhi oleh pengalaman menggunakannya yang erat kaitannya dengan kepuasan (De Vos dkk, 2015; Gebeyehu dan Takano, 2008; Shiftan dkk, 2015). Kelompok choice user pekerja tidak akan menggunakan (lagi) transportasi umum ketika merasa tidak puas dengan layanannya.

\section{DAFTAR PUSTAKA}

Abenoza, Roberto F., Oded Cats dan Yusak O. Susilo. 2017. Travel satisfaction with public transport : Determinants, user classes, regional disparities and their evolution. Transportation Research Part A 95 (2017) pp. 64-84.

Alvi, Mohsin. 2016. A Manual for Selecting Sampling Techniques in Research. MPRA Paper No. 70218.

Beimborn, Edward A., Michael J. Greenwald, Xia Jin. 2003. Transit accessibility and connectivity impacts on transit choice and captivity. Center for Urban Transportation Studies and Department of Urban Planning University of Wisconsin-Milwaukee.

Chowdhury, Subeh, Avishai Ceder dan Bruno Velty. 2014. Measuring public-transport network connectivity using Google Transit with comparison across cities. Journal of Public Transportation, Vol. 17, No. 4.

Chuen, Onn Chiu, Mohamed Rehan Karim dan Sumiani Yusoff. 2014. Mode choice between private and public transport in Klang Valley, Malaysia. The Scientific World Journal, Vol. 2014, Article ID 394587.

Corpuz, Grace. 2007. Public transport or private vehicle factors that impact on mode choice. 30th Australasian Transport Research Forum, January 2007.

De Vos, Jonas, Patricia L. Mokhtarian Veronique Van Acker dan Frank Witlox. 2016. Travel mode choice and travel satisfaction. Transportation Vol. 43, pp. 771-796.

Gebeyehu, Mintesnot dan Shin-ei Takano. 2008. Modeling the relationship between travelers' level of satisfaction and their mode choice behavior. Journal of the Transportation Research Forum, Vol. 47, No. 2 (Summer 2008), pp. 103-118.

Hair Jr., Joseph F., William C. Black, Barry J. Babin dan Rolph E. Anderson. 2010. Multivariate Data Analysis. Pearson Prentice Hall. 
Iacobucci, Dawn. 2009. Structural equations modeling : Fit Indices, sample size, and advanced topics. Journal of Consumer Psychology, 20 (2010) pp.90-98.

Jenatabadi, Hashem Salarzadeh. n/d. A Critical Story about Sample Size, Outliers, and Normality Criteria in Structural Equation Modelling. Department of Science and Technology Studies University of Malaya, Kuala Lumpur, Malaysia.

Lierop, Dea van dan Ahmed El-Geneidy. 2016. Enjoying loyalty : The relationship between service quality, customer satisfaction, and behavioral intentions in public transit. Research in Transportation Economics 59 pp. 50-59.

Papaioannou, Dimitrios dan Luis Miguel Martinez. 2015. The role of accessibility and connectivity in mode choice. Transportation Research Procedia 10 p. 831 - 839.

Schreiber, James B., Frances K. Stage, Jamie King, Amaury Nora, Elizabeth A. Barlow. 2006. Reporting Structural Equation Modeling and Confirmatory Factor Analysis Results. Heldref Publications.

Shiftan, Yoram, Yotam Barlach dan Daniel Shefer. 2015. Measuring passenger loyalty to public transport modes. Journal of Public Transportation, Vol. 18, No. 1.

Suhari. 2008. Pengaruh penerapan Pertamina Way terhadap kualitas pelayanan dalam rangka meningkatkan loyalitas. Tesis, Prodi Magister Manajemen Fakultas Ekonomika dan Bisnis Universitas Diponegoro.

Tamin, Ofyar Z. 2000. Perencanaan dan pemodelan transportasi. Penerbit ITB, Bandung.

Wang, Dong dan Yan Liu. 2015. Factors influencing public transport use : A study of university commuters' travel and mode choice behaviours. State of Australian Cities Conference 2015.

2014. Rencana Detail Tata Ruang Kawasan Perkotaan Pati. Badan Perencanaan Pembangunan Daerah Kabupaten Pati.

2015. Rencana Umum Jaringan Transportasi Jalan Kabupaten Pati. Badan Perencanaan Pembangunan Daerah Kabupaten Pati. 